\title{
СУЧАСНА ПАРАДИГМА УПРАВЛІННЯ ЗАКЛАДОМ ОХОРОНИ ЗДОРОВ'Я В УМОВАХ ПРОВЕДЕННЯ МЕДИЧНОЇ РЕФОРМИ
}

\author{
Светлана Назарко
}

\section{СОВРЕМЕННАЯ ПАРАДИГМА УПРАВЛЕНИЯ УЧРЕЖДЕНИЕМ ЗДРАВООХРАНЕНИЯ В УСЛОВИЯХ ПРОВЕДЕНИЯ МЕДИЦИНСКОЙ РЕФОРМЫ}

\author{
Svitlana Nazarko
}

\section{MODERN PARADIGM OF MANAGEMENT OF HEALTH CARE MANAGEMENT IN THE CONDITIONS OF MEDICAL REFORM}

У статті розглянуто процес переходу від адміністративної до економічної моделі управління закладом охорони здоров'я. Визначено можливість і специфіку застосування соиіально-економічного та системного підходів до економічного управління закладом охорони здоров'я з урахуванням форми власності та сфери діяльності. Розглянуто вимоги до кандидатів на зайняття керівних посад у медичних закладах та виокремлено нові знання та вимоги, якими повинні володіти в Україні керівники медичних закладів. 3'ясовано, цо основний критерій маркетингу медичного закладу в час ринкової економіки - конкуренція якістю.

Ключові слова: заклади охорони здоров'я; економічне управління; механізм управління.

Рис.: 1. Бібл.: 15.

В статье рассматривается прочесс перехода от административной к экономической модели управления учреждением здравоохранения. Определена возможность и специфику применения сочиально-экономического и системного подходов к экономическому управления учреждением здравоохранения с учетом формы собственности и сферы деятельности. Рассмотрены требования к кандидатам на занятие руководящих должностей в медицинских учреждениях и выделены новые знания и требования, которыми должны обладать в Украине руководители медицинских учреждений. Установлено, что основной критерий маркетинга медицинского учреждения, во время рыночной экономики - конкуренция качеством.

Ключевые слова: учреждения здравоохранения; экономическое управление; механизм управления.

Рис.: 1. Библ.: 15.

The article discusses the process of moving from an administrative to an economic model of managing a healthcare facility. The possibility and specifics of the application of socio-economic and systematic approaches to the economic management of the health care institution with regard to the ownership and sphere of activity are determined. Requirements for candidates for management positions in medical institutions are considered, and new knowledge and requirements that heads of medical institutions in Ukraine must possess are highlighted. It has been found that the main criterion for marketing a health care institution in the market economy is quality competition.

Keywords: health care institutions; economic management; management mechanism.

Fig.: 1. References: 15.

JEL Classification: I15

Постановка проблеми. Донедавна в медичній галузі панували методи адміністративного управління, які на тлі фінансування стали фундаментом екстенсивного розвитку закладів охорони здоров'я. Сьогодні в ринковому економічному середовищі цей шлях розвитку вичерпав свій потенціал, оскільки система не здатна використовувати економічні інструменти, важелі та стимули до пошуку нових типів закладів охорони здоров'я, а також підвищення якості спеціалізованих послуг, надання альтернативних форм методичної допомоги тощо, - це в сукупності створює основу для посилення дисбалансу та збільшення медичних, економічних та соціальних втрат.

Відповідно, нові ринкові реалії вимагають переформатування медичної галузі із застосуванням нових підходів до управління закладом охорони здоров'я. Саме тому дослідження спрямоване на вирішення проблеми застосування системного підходу до управління медичним закладом у контексті медичної реформи.

Аналіз досліджень і публікацій. Аналізу теоретичних і практичних аспектів підвищення ефективності управління медичними закладами та його значення для економічного зростання, присвячені праці багатьох дослідників, серед яких варто виділити роботи: В. А. Грабовського, О.В.Дмитрука, В. М. Лехан, О. А. Мартинюка, Л. А. Мельника, Г. О. Слабкого, С. О. Смирнова, Л. С. Стефанишина, Л. І. Федулової, 3. В. Юринця, Т. М. Ямненка.

(C) Назарко С. O., 2019 
ГАЛУЗЕВИЙ АСПЕКТ РОЗВИТКУ НАЦІОНАЛЬНОГО ГОСПОДАРСТВА

Виділення недосліджених частин загальної проблеми. Однак, попри достатню кількість наукових публікацій, сьогодні окреслено коло проблем щодо ефективного управління медичними закладами на мікрорівні, які грунтуються на застосуванні економічних методів і потребують подальшого дослідження.

Мета статті. Метою роботи є дослідження теоретичних аспектів та обгрунтування та розробка практичних рекомендацій щодо систематизації компонентів механізму ефективного управління медичними закладами в сучасних економічних умовах.

Відповідно до поставленої мети були визначені такі завдання дослідження: проаналізувати кадрову політику в медичних установах; розглянути теоретичні аспекти підвищення якості медичного обслуговування із впровадженням сучасних науково обгрунтованих медичних стандартів; обгрунтувати ключові фактори конкурентоспроможності медичних закладів.

Виклад основного матеріалу. Процес управлінських рішень у медичних установах стає складнішим, враховуючи дедалі більшу різноманітність аспектів, що визначають реалістичність та потенційну ефективність таких рішень у сучасному контексті. Зміни, що відбуваються в медичній галузі, лімітне фінансування закладів охорони здоров'я, зростаючі потреби пацієнтів у якісній медичній допомозі, поширення сучасних методів лікування та діагностики - це фактори, що формують зовсім інші вимоги до всіх учасників відносин у сфері медицини [12].

У межах вітчизняної медичної реформи пропонується перекласти функції замовника медичних послуг на заклад, який буде розподіляти фінансові ресурси за рахунок платних послуг пацієнтам. Таким чином, держава рухається від підтримки мережі закладів охорони здоров'я, які надають безкоштовні послуги, до придбання послуг у цій мережі. Постачальником послуг визначено медичні заклади, а споживачами медичних послуг - пацієнтів. Відповідно до реформи передбачено формування автономного замовника послуг, автономних постачальників, які продаватимуть замовнику послуг медичні послуги, грунтуючись на підписанні договорів. Як перспектива - створення контролюючого органу чи наглядової ради. Отже, метою всіх державних дій має стати єдиний ринок медичних послуг (медичний простір), який об'єднуватиме всіх постачальників (установи, заклади охорони здоров'я), зокрема приватні медичні центри, заклади, аптеки тощо [1].

Однак у моделі збалансованого трикутника дій «споживач - замовник - постачальник» (рис. 1) відсутній важливий елемент - інноваційна компонента. Існуюча національна модель таких відносин недосконала, оскільки в ній практично не бере участі національний виробник інновацій (нових лікарських засобів, медичної техніки й виробів медичного призначення), а замовника послуг практично не існує, оскільки він інтегрований із постачальником. У ролі постачальника виступає держава, яка володіє закладами охорони та забезпечує їхнє утримання. Така ситуація не сприяє розв'язанню конфлікту інтересів усіх зацікавлених сторін, що призводить до низьких результатів (надання медичної допомоги та медичних послуг) при значних національних витрат на охорону здоров’я [2].

Отже, потрібно запровадити інноваційні підходи та елементи професійного менеджменту, адекватні трансформаційним процесам у галузі медицини, для покращення індикаторів якості всіх складових системи управління закладом охорони здоров'я: piвень кваліфікації медичного персоналу; сучасне обладнання, інноваційні та інформаційні технології із вдосконаленням автоматизованих електронних систем обробки інформації та систематичним покращенням якості та повноти медичної інформації; здатність максимально повно задовольняти потреби споживача, забезпечуючи повний спектр високоякісних медичних послуг. 


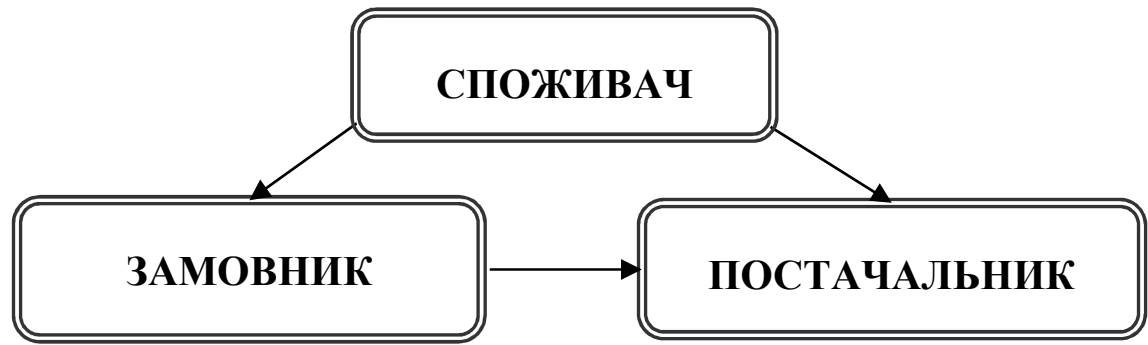

Рис. 1. Збалансований трикутник дій

Отже, вдосконалити управлінську систему медичним закладом та підвищення якості такого управління, що $є$ необхідною умовою забезпечення його конкурентоспроможності на ринку медичних послуг, при переході до автономної моделі діяльності, доцільно реалізувати такі принципи [5].

Серед перших - принцип цілеспрямованості, який акумулює всі компоненти процесу управління. Специфіка його впровадження в закладах охорони здоров'я полягає в необхідності висвітлення цілей медичного, організаційного, технологічного та фінансово-економічного змісту з підпорядкуванням останніх першим двом.

Інший принцип полягає саме в управлінні медичним закладом і враховує - безпеку, яка $\epsilon$ основоположним принципом надання медичної допомоги населенню та пріоритетним критерієм забезпечення та оцінки його якості. Реалізація цього принципу вимагає комплексних системних зусиль, що включає широкий спектр професійних, організаційних, правових та психологічних заходів щодо поліпшення процесу діагностики та лікування, забезпечення реальних умов управління ризиками (включаючи безпеку застосування лікарських засобів i використання медичного обладнання), санітарноепідеміологічний контроль, безпеку клінічної практики та безпечну ситуацію в медичних установах [11].

Одним із першочергових напрямів - це ефективна кадрова політика (питання підготовки, підвищення мотиваційної складової, розподілу медичних кадрів тощо) $є$ ключовим напрямом ефективного управління закладом охорони здоров'я, оскільки від професійного рівня медичних працівників залежить якість, своєчасність і доступність надання медичної допомоги пацієнтам [8].

Нині у вітчизняних медичних закладах бракує менеджерів-організаторів у сфері охорони здоров’я, які були б здатні застосовувати широкий спектр практичних навичок та приймати ефективні стратегічні рішення, що необхідні для зміни на організаційному рівні, і глибокого розуміння викликів та новітніх тенденцій у галузі охорони здоров'я. Така ситуація пояснюється відсутністю ефективної системи підготовки керівників медичних закладів та несформованістю освітньої бази щодо досягнень як провідних країн світу, так і реалій вітчизняної медичної системи [10].

Особливу увагу необхідно приділити тому, що керівники медичних закладів у розвинених країнах світу - це фахівці, які володіють достатнім багажем теоретикопрактичних знань із менеджменту, економіки, права, поведінкових наук, доказової медицини тощо. А у вітчизняних закладах охорони здоров'я значна частина управлінців лікарі-практики з медичною освітою.

3 часу реформи медичної галузі в Україні постійно тривають дискусії щодо стану управління медичним закладом та його керівного складу, а також відповідність освіти займаній посаді. На сьогодні головний лікар медичного закладу виконує функції як адміністративні, так і медичні. Незважаючи на те, що ці заклади перебувають на утриманні держави, це величезний обсяг роботи. Тому ми маємо брати приклад із розвинених країн, де управлінські функції є структурованими, наприклад, адміністративними питаннями займається менеджер, медичними процесами - медичний фахівець тощо [7]. 
ГАЛУЗЕВИЙ АСПЕКТ РОЗВИТКУ НАЦІОНАЛЬНОГО ГОСПОДАРСТВА

31 січня 2019 року в Україні в межах реформи охорони здоров'я ввели розмежування посад і функцій у медичних установах: медичними питаннями буде займатись медичний директор, а господарськими питаннями - директор установи. Ніхто не буде звільнений, усі медичні працівники на чолі з головним лікарем будуть виконувати свої функції до закінчення терміну дії контракту [4].

Після закінчення дії контракту медичні працівники мають подати свої кандидатури на конкурс генерального або медичного директора закладу охорони здоров'я і в разі проходження до 2022 року кандидат може обіймати посаду з будь-якою вищою освітою (лікар, економіст, гуманітарною освітою i т. ін.). А відповідно до наказу від 31.10.2018 р. № 1977, затвердженого МОЗ України, з 2022 року всі претенденти на зазначені посади повинні здобувати управлінську чи менеджерську освіту в галузі знань «Управління та адміністрування» або «Публічне управління та адміністрування» [13].

Як уже зазначалося, проблеми, пов'язані з кадровими ресурсами охорони здоров'я, не тільки стосуються медичного закладу, а лежать в основі формування державної політики Серед невідкладних завдань, розробка професійних стандартів із дотриманням європейських вимог та програм для підготовки. Це дасть змогу сформувати єдині підходи до встановлення відповідності номенклатури та кваліфікаційних вимог до посад і характеристик спеціальностей.

Сучасні трансформаційні зміни в галузі охорони здоров'я спонукають медичні кадри до безперервного навчання і професійного розвитку (відповідно до постанови Кабміну № 302 від 28 березня 2018 року), які здатні до адаптації в умовах їх функціонування. Таким чином, сучасна ситуація у вітчизняній охороні здоров'я вимагає проведення глибинних перетворень і оновлення змісту і форми підготовки керівних кадрів, впровадження дуальної освіти або альтернативних форм, таких як дистанційне навчання [8].

Отже, застосування системного підходу в управлінні закладами охорони здоров'я об'єднує сукупність взаємопов'язаних елементів: ресурси та інформація, надання медичної послуги і зв'язок із зовнішнім середовищем (з урахуванням політичної, економічної, соціально-демографічної, культурної ситуації та інфраструктури конкретного об'єкта). На сьогодні в реформаційних умовах такий підхід є найбільш перспективним і дозволяє елементи ефективного управління медичними закладами реалізувати на практиці не лише на мікрорівні, але й у контексті трансформації вітчизняної системи охорони здоров'я $[3 ; 11]$.

Висновки і пропозиції. Всупереч новим виклики і реформаційним змінам трансформація медичної системи уповільнюється, оскільки медичні заклади є досить консервативним елементом системи охорони здоров'я. Функціонуючи на ринку медичних послуг, заклади охорони здоров'я для підтримки конкурентоспроможності мають враховувати фактори впливу ендогенного та екзогенного характеру пов'язані з реформуванням галузі та процесами децентралізації, до яких слід віднести: змінити методи планування та організації діяльності медичних закладів; впровадження нових моделей управління; застосування сучасних форм оплати медичних послуг; новаторство в частині формування електронної системи охорони здоров'я (E-Health); інноватизація інформаційно-аналітичного забезпечення; підвищити професійний рівень кадрового потенціалу; дотримання міжнародних стандартів якості надання медичних послуг.

\section{Список використаних джерел}

1. Бутко М. П., Колоша В. П., Попело О. В. Особливості локалізації економічного простору регіонів в умовах децентралізації владних повноважень. Економіка України. 2019. № 1. С. 60-74.

2. Бутко М., Тульчинський Р. Принципи становлення нового регіоналізму з використанням системного підходу. Проблеми і перспективи економіки та управління: науковий журнал. 2018. № 2 (14). С. 49-56. 
ГАЛУЗЕВИЙ АСПЕКТ РОЗВИТКУ НАЦІОНАЛЬНОГО ГОСПОДАРСТВА

3. Грабовський В. А., Клименко П. М. Системний підхід до управління закладами охорони здоров'я. Вісник Національної академії державного управління при Президентові Украйни. 2014. № 3. C. 136-142.

4. Дмитрук О. В. Управління адаптацією персоналу закладів охорони здоров'я в нових умовах господарювання. Приазовський економічний вісник. 2018. Вип. 5(10). С. 182-186. URL: http://pev.kpu.zp.ua/journals/2018/5_10_uk/33.pdf.

5. Ефективне управління медичними закладами. Можливості MIC. URL: https://euromd.com.ua/post-8164-efektivne-upravlinnya-medichnimi-zakladami-mozhlivosti-mis.

6. Мартинюк О. А., Курдибанська Н. Ф. Впровадження системи управління якістю в медичних закладах. Причорноморські економічні студії. 2016. Вип. 6. С. 75-79.

7. Мельник Л. А. Сучасний керівник медичного закладу в умовах реформування здоровоохоронної галузі. Державне управління: удосконалення та розвиток. 2018. № 11. URL: http://www.dy.nayka.com.ua/?op=1\&z=1336.

8. Модернізація менеджменту системи охорони здоров'я в умовах проведення медичної реформи. Аналітична записка за матеріалами науково-практичної конференції 3 міжнародною участю, Тернопіль-Кам'янець-Подільський, 12-13 грудня 2018 року. URL: http://dspace.tneu.edu.ua/bitstream/316497/33636/1/pdf.

9. Науковий Менеджмент в медицині. URL: http://angio-veritas.com/innovatsiji/naukovoinnovatsijnyj-menedzhment.

10. Продовження медичної реформи: що зміниться у 2019 році? URL: http://yurgazeta.com/prodovzhennya-medichnoyi-reformi-shcho-zminitsya-u-2019-roci.html.

11. Смирнов С. О., Бикова В. Г. Механізм економічного управління закладами охорони здоров’я. Управління розвитком. 2016. № 3. С. 78-83.

12. Стефанишин Л. С. Теоретико-методичні основи застосування партисипативного управління закладом охорони здоров'я. Держава та регіони. Серія: Економіка та підприємництво. 2019. № 3. С. 160-166.

13. Устінов О. В. Управління медичним закладом в процесі реформи: що необхідно і чого не слід робити. Украйнський медичний часопис. URL: https://www.umj.com.ua/article/127584.

14. Юринець 3. В., Петрух О. А. Напрями державного регулювання інноваційного розвитку сфери охорони здоров'я України. Інвестииії: практика та досвід. 2018. № 22. С. 116-121.

15. Ямненко Т. М. Медична реформа: реалії України та міжнародний досвід. Юридичний вісник. Повітряне і космічне право. 2018. № 2. С. 116-120.

\section{References}

1. Butko, M. P., Kolosha, V. P., Popelo, O. V. (2019). Osoblyvosti lokalizatsii ekonomichnoho prostoru rehioniv $\mathrm{v}$ umovakh detsentralizatsii vladnykh povnovazhen [Features of localization of economic space of regions in the conditions of decentralization of powers]. Ekonomika Ukrainyn Ukraine economy, 1, 60-74 [in Ukrainian].

2. Butko, M., Tulchynskyi, R. (2018). Pryntsypy stanovlennia novoho rehionalizmu z vykorystanniam systemnoho pidkhodu [Principles for the formation of new regionalism by using the system approach]. Problemy i perspektyvy ekonomiky ta upravlinnia - Problems and prospects of economics and management, 2 (14), 49-56 [in Ukrainian].

3. Hrabovskyi, V. A., Klymenko, P. M. (2014). Systemnyi pidkhid do upravlinnia zakladamy okhorony zdorovia [System approach to management of health care institutions]. Visnyk Natsionalnoi akademii derzhavnoho upravlinnia pry Prezydentovi Ukrainy - Administration under the President of Ukraine, 3, 136-142 [in Ukrainian].

4. Dmytruk, O. V. (2018). Upravlinnia adaptatsiieiu personalu zakladiv okhorony zdorovia v novykh umovakh hospodariuvannia [Managing the adaptation of health care staff in the new business environment]. Pryazovskyi ekonomichnyi visnyk - Azov Economic Bulletin, 5(10), 182-186. URL: http://pev.kpu.zp.ua/journals/2018/5_10_uk/33.pdf.

5. Efektyvne upravlinnia medychnymy zakladamy. Mozhlyvosti MIS [Effective management of medical facilities. MIS capabilities]. (2017). Retrieved from https://euromd.com.ua/post-8164efektivne-upravlinnya-medichnimi-zakladami-mozhlivosti-mis. 
ГАЛУЗЕВИЙ АСПЕКТ РОЗВИТКУ НАЦІОНАЛЬНОГО ГОСПОДАРСТВА

6. Martyniuk, O. A., Kurdybanska, N. F. (2016). Vprovadzhennia systemy upravlinnia yakistiu v medychnykh zakladakh [Implementation of quality management system in medical institutions]. Prychornomorski ekonomichni studii - Black Sea Economic Studies, 6, 75-79 [in Ukrainian].

7. Melnyk, L. A. (2018). Suchasnyi kerivnyk medychnoho zakladu v umovakh reformuvannia zdorovookhoronnoi haluzi [The modern head of a medical institution in the conditions of reforming the health care industry]. Derzhavne upravlinnia: udoskonalennia ta rozvytok-Public Administration: Improvement and Development, 11. Retrieved from http://www.dy.nayka.com.ua/?op=1\&z=1336.

8. Modernizatsiia menedzhmentu systemy okhorony zdorovia $v$ umovakh provedennia medychnoi reformy. Analitychna zapyska za materialamy naukovo-praktychnoi konferentsii z mizhnarodnoiu uchastiu, Ternopil-Kamianets-Podilskyi, 12-13 hrudnia 2018 roku [Modernization of health care management in the context of medical reform. Analytical note on the materials of a scientific conference with international participation, Ternopil-Kamianets-Podilsk] (2018). Retrieved from http://dspace.tneu.edu.ua/bitstream/316497/33636/1/pdf.

9. Naukovyi Menedzhment v medytsyni [Scientific Management in Medicine]. (2019). Retrieved from http://angio-veritas.com/innovatsiji/naukovo-innovatsijnyj-menedzhment.

10. Prodovzhennia medychnoi reformy: shcho zminytsia u 2019 rotsi? [Continuing medical reform: what will change in 2019?]. (2019). Retrieved from http://yur-gazeta.com/prodovzhennyamedichnoyi-reformi-shcho-zminitsya-u-2019-roci.html.

11. Smyrnov, S. O., Bykova, V. H. (2016). Mekhanizm ekonomichnoho upravlinnia zakladamy okhorony zdorovia [Mechanism of economic management of health care facilities]. Upravlinnia rozvytkom - Development Management, 3, 78-83 [in Ukrainian].

12. Stefanyshyn, L. S. (2019). Teoretyko-metodychni osnovy zastosuvannia partysypatyvnoho upravlinnia zakladom okhorony zdorovia [Theoretical and methodological bases of application of partisipative management of a health care facility]. Derzhava ta rehiony. Seriia: Ekonomika ta pidpryiemnytstvo - State and Regions. Series: Economics and Entrepreneurship, 3, 160-166 [in Ukrainian].

13. Ustinov, O. V. (2018). Upravlinnia medychnym zakladom v protsesi reformy: shcho neobkhidno i choho ne slid robyty [Managing a health care facility in the reform process: what should and should not be done]. Ukrainskyi medychnyi chasopys - Ukrainian Medical Journal. URL: https://www.umj.com.ua/article/127584.

14. Yurynets, Z. V., Petrukh, O. A. (2018). Napriamy derzhavnoho rehuliuvannia innovatsiinoho rozvytku sfery okhorony zdorovia Ukrainy [Areas of state regulation of innovative development of health care in Ukraine]. Investytsii: praktyka ta dosvid - Investments: Practice and Experience, 22, 116-121 [in Ukrainian].

15. Yamnenko, T. M. (2018). Medychna reforma: realii Ukrainy ta mizhnarodnyi dosvid. Yurydychnyi visnyk [Medical reform: the realities of Ukraine and international experience]. Povitriane i kosmichne pravo - Legal Bulletin. Air and space law, 2, 116-120 [in Ukrainian].

|Назарко Світлана Олексіївна - кандидат економічних наук, доцент, заступник директора 3 науковопедагогічної роботи Чернігівського інституту МАУП (вул. Промислова, 17, м. Чернігів, 14017, Україна).

Назарко Светлана Алексеевна - кандидат экономических наук, доцент, заместитель директора по научнопедагогической работе Черниговского института МАУП (ул. Промышленная, 17, г. Чернигов, 14017, Украина).

Nazarko Svitlana - PhD in Economics, Associate Professor, Deputy Director-rector of Chernihiv Institute of the

Inter-Regional Akademy of Personnel Management (17 Promyslova Str., 14017 Chernihiv, Ukraine).

E-mail: s.nazarko@ukr.net

ORCID: https://orcid.org/0000-0002-4841-9201

Назарко С. Сучасна парадигма управління закладом охорони здоров'я в умовах проведення медичної реформи. Проблеми і перспективи економіки та управління. 2019. № 4 (20). С. 170-175. 